\title{
Successes and Failures of United Nations Peace Operations
}

\section{B. Pushkina}

For citation: Pushkina D. B. Successes and Failures of United Nations Peace Operations. Vestnik of Saint Petersburg University. History, 2020, vol. 65, iss. 1, pp. 261-277.

https://doi.org/10.21638/11701/spbu02.2020.115

What does 'success' in peace operations mean? Is it purely the absence of hostilities or should it also be measured in terms of civilian suffering? Did a UN peacekeeping mission succeed because it fulfilled its mandate of monitoring elections or did it fail because it was not able to prevent civilian massacres in the areas where peacekeepers were deployed? Peace operations conducted by the United Nations remain under close scrutiny from both scholars and practitioners. This article examines the existing measures of UN's effectiveness, proposes a new scale of measurement of successes and failures of UN PKO's and examines 6 cases of UN PKO's in Africa (UNTAG in Namibia, ONOMOZ in Mozambique, UNAMIR in Rwanda, UNOSOM in Somalia, MINURCA in Central African Republic, ONUB in Burundi) across proposed measures. The definition of success offered in this article (limiting violent conflict, reducing human suffering, preventing conflict from spreading, and preventing war from recurring) does two important things: 1) it acknowledges the different nuances, voices, and forces international and domestic, societal and institutional - affecting whether a mission may or may not be considered successful; 2) it insists that the human dimension remains the primary criterion for such considerations. A more nuanced consideration of "success" and a close look at so many cases is relevant not only to conceptual debates about these issues but also to "real" policy in the past, present, and future. The article concludes that the suggested measures of success/failure lead to a more nuanced evaluation of UN's performance.

Keywords: United Nations, Peacekeeping Operations, International Security, Intra-state conflicts, History of UN PKO'.

\section{Успехи и неудачи миротворческих операций ООН}

\section{Д.Б. Пушкина}

Для цитирования: Pushkina D.B. Successes and Failures of United Nations Peace Operations // Вестник Санкт-Петербургского университета. История. 2020. Т.65. Вып.1. С.261-277. https://doi.org/10.21638/11701/spbu02.2020.115

Что означает успех в миротворческих операциях? Простое ли это отсутствие военных действий, или же успех должен измеряться с точки зрения страданий гражданского

Daria B. Pushkina - PhD, Associate Professor, St. Petersburg State University, 7-9, Universitetskaia nab., St. Petersburg, 199034, Russian Federation; d.pushkina@spbu.ru

Дарья Булатовна Пушкина - PhD, доцент, Санкт-Петербургский государственный университет, Российская Федерация, 199034, Санкт-Петербург, Университетская наб., 7-9; d.pushkina@spbu.ru

Acknowledgements: Aleksandra Plucinski, Connecticut College, Editing \& Research Assistant.

Автор благодарит Александру Плучински за исследовательскую и редакторскую поддержку.

(c) Санкт-Петербургский государственный университет, 2020 
населения? Была ли миротворческая миссия ООН успешной, потому что выполнила свой мандат по наблюдению за выборами, или провалилась, потому что не смогла предотвратить массовые убийства гражданских лиц в районах дислокации миротворцев? Миротворческие операции, проводимые Организацией Объединенных Наций, находятся под пристальным вниманием как ученых, так и практиков. Документы ООН рассматривают эффективность миссий как выполнение или невыполнение мандата. В академических кругах существует убеждение, что миротворческие миссии ООН необходимо рассматривать по более широким критериям, но отсутствует консенсус, какими должны быть данные критерии. В настоящей статье рассматриваются существующие показатели эффективности ООН, предлагается новая шкала оценки успехов и неудач операций по поддержанию мира ООН (OПМ OOH), а также анализируются шесть случаев ОПМ ООН в Африке (ЮНТАГ - Намибия, ЮНОМОЗ - Мозамбик, МООНПР - Руанда, ЮНОСОМ - Сомалия, МООНЦАР - Центральная Африканская Республика, ОНЮБ - Бурунди) по предлагаемым автором данной статьи критериям. Оценка эффективности миротворческих миссий ООН в гражданских войнах, предложенная в статье, включает следующие критерии: ограничение конфликта (военных действий), снижение человеческих жертв, предотвращение распространения конфликта за пределы страны боевых действий, создание стабильной обстановки, способной предотвратить возобновление конфликта после того, как миссия завершена. Данные критерии предполагают не только вклад в академическую литературу по ООН, но и могут быть полезны для формирования политики в области миротворчества. Автор приходит к выводу, что предлагаемые критерии успеха/неудачи способствуют более детальной оценке миротворческой деятельности ООН.

Ключевые слова: Организация Объединенных Наций, миротворческие операции, международная безопасность, внутригосударственные конфликты, история операций ООН по поддержанию мира.

What does "success" in peace operations mean? Is it purely the absence of hostilities or should it also be measured in terms of civilian suffering? Did a UN peacekeeping mission succeed because it fulfilled its mandate of monitoring elections or did it fail because it was not able to prevent civilian massacres in the areas where peacekeepers were deployed? Peace operations conducted by the United Nations remain under close scrutiny from both scholars and practitioners. There are numerous works devoted to analysis of such operations and they often disagree as to how to evaluate the same missions and, more broadly, how to define and understand "success" in peacekeeping. Ultimately, the question of what "success" is depends on our understanding of what peace is as well as what the obligations of the United Nations are with regards to keeping peace. Careful analysis of what constitutes success of peace operations is important not only from the scholarly perspective but also, perhaps most importantly, from the policy-making side.

Ideally, peace operations can significantly contribute to durable peace ${ }^{1}$. In a less ideal world, one can distinguish between negative peace (absence of violence) and positive peace (resolution of the causes of conflict) ${ }^{2}$, as well as between the concept of peace of the international community and local visions. Thus, various measures of success of peacekeeping range from stopping violence and maintaining cease-fires ${ }^{3}$ to building a stable

1 Galtung J. Violence, Peace, and Peace Research // Journal of Peace Research. 1969. Vol. 6, iss. 3. P. 167.

2 Doyle M. et al. Making War and Building Peace: United Nations Peace Operations. Princeton. 2006.

3 Heldt B. et al. Peacekeeping Operations: Global Patterns of Intervention and Success, 1940-2000. Stockholm, 2007; Stedman R. et al. Ending Civil Wars: The Implementation of Peace Agreements. Boulder, 2002; Fortna V. Does peacekeeping work? Shaping Belligerents' Choice After Civil War. Princeton, 2008. 
democracy with a developed economy ${ }^{4}$; from bringing justice and equity ${ }^{5}$ to even denying the validity of evaluation along these lines and seeing peacekeeping as a tool of the current world system that imposes "liberal imperialism".

There have been several attempts within contemporary peacekeeping literature to create a typology of varying effectiveness of UN peace operations. Some earlier attempts were geared more towards the traditional focus of UN peacekeeping - international conflicts ${ }^{7}$. Diehl suggests that two primary standards of success are 1) limitation of violent conflict ("to prevent the onset or renewal of warfare, as well as to limit the death and destruction of violent incidents short of war") and 2) conflict resolution ("to facilitate the resolution of the disagreements underlying the conflict") ${ }^{8}$. However, the particulars and frequency of intra-state wars ${ }^{9}$ have led scholars to define specific criteria for the success of UN peacekeeping operations in intra-state violent conflicts.

Several qualitative studies have attempted to compare missions based on more elaborate criteria for evaluating success. Most of the studies described below continue to put mandate fulfillment first. They then attempt to evaluate how and whether UN missions accomplished wider goals. The authors differ as to how to define the wider goals, although they usually agree that peacekeepers should limit violent conflict during deployment and preferably create conditions to eliminate its resurgence after the mission's departure. An extremely important aspect of the evaluation of peace missions is their long-term contribution to peace in the conflict-ridden country. Kathman and Wood ${ }^{10}$ point out that success must be measured over time and claim that an important factor of peacekeeping success is the ability to establish a long-term presence. Scholars often differ in what other criteria they take into account when evaluating deeper and longer-term effects of the UN missions - for example, whether to look at power-sharing arrangements in detail or evaluate whether order is upheld by the government or evaluate the level of economic development, etc.

More recently, the reduction of human suffering [the condition of the civilian population during missions' deployment], is a measure/priority that has become increasingly significant in discussions of the UN's role, including discussing the recent role of UN peacekeepers in the protection of civilians. Doyle and Sambanis ${ }^{11}$ stress that "successful implementation of a narrow peacekeeping mandate is not sufficient for a successful peace process." They suggest ${ }^{12}$ that "peace-building success is a function of the success of peace operations, and that success can be measured in terms of the degree to which the mandate was implemented and by whether or not a stable peace was attained..."

Following the above-mentioned authors, Howard ${ }^{13}$ evaluates peacekeeping missions based on 1) mandate implementation, and 2) broader assessment of the state of the country

${ }^{4}$ Paris R. At War's End Building Peace after Civil Conflict. Cambridge, 2004.

${ }^{5}$ Cousens E. et al. Peacebuilding as Politics: Cultivating Peace in Fragile Societies. Boulder, 2000.

${ }^{6}$ Pugh M. Peacekeeping and Critical Theory // International Peacekeeping. 2004. Vol. 11, iss. 1. P. 3958.

7 Diehl P. International Peacekeeping. Baltimore, 1993.

8 Ibid. P. 36-37.

9 Brown M. (ed.) International Dimensions of Internal Conflict. Cambridge, 1996.

10 Wood R. et al. Armed Intervention and Civilian Victimization in Intrastate Conflicts // Journal of Peace Research. 2012. Vol. 49, iss. 5. P. 647-660.

${ }^{11}$ Doyle M. et al. Making War and Building Peace: United Nations. P.27.

12 Ibid.

13 Howard L. UN Peacekeeping in Civil Wars. Cambridge, 2008. 
after UN intervention (examining to what extent the institutions that the UN monitored, reformed or created functioned after UN withdrawal). Howard categorizes the missions as successes, mixed successes and failures. Diehl and Druckman ${ }^{14}$ offer a comprehensive list of what to look for when determining success: humanitarian aid, conduction of elections, local governance, rule of law and other factors, and suggest operational definitions of these criteria in their chapters. The most recent contribution to this debate is the work of Martin-Brûlé ${ }^{15}$ who has proposed a new conceptual framework which further delineates operational definitions of success or failure based on: failures, partial failures, partial successes or successes. We recognise that this approach allows for a more in-depth evaluation of each mission whilst also delimiting analysis to four broad categories (thus safeguarding against intellectual incoherence). It is for these reasons that we have adopted this typology when carrying out our analyses.

Some previous attempts to evaluate peace operations have been too narrow or overly simplified complex events and interactions, or even been hubristic about what the UN can accomplish and/or how thoroughly scholars can judge UN performance. That means a more modest, nuanced look at the UN that takes complexity and messiness into account and admits that human behavior and politics can't always be precisely quantified is going to be more intellectually rigorous and rewarding than a grand unified theory. To do so, one needs to engage with the insights of other fields (IR, comparative politics, peace studies) which will help develop such a "mid-range" theory that allows for some generalization and comparison across cases without sacrificing particular knowledge in pursuit of elegance.

Taking the aforementioned debates in the literature into account, in an attempt to draw a systematic scale of peace operation evaluation, this article suggests four criteria against which to evaluate UN peace operations in civil wars: limiting violent conflict in the host state, reduction of human suffering, preventing the spread of conflict beyond the borders of the host state, promoting conflict resolution ${ }^{16}$. These criteria would add to UN's own definition of success of the peacekeeping missions, that is, mandate assessment (internal effectiveness).

The criteria offered in this article follow ideas of both scholars and practitioners and attempt to balance several dilemmas of evaluation of peace operations: between peace and justice, objectives and outcomes, external and internal outcomes, international, regional and local dimensions.

- Criterion 1. Limiting violent conflict in the host state is the primary goal of peacekeeping. Since peacekeepers are often deployed after a ceasefire agreement is in place, the peacekeepers' task is often to maintain that peace. This is a particularly challenging task in intrastate conflicts where various military factions may continue fighting despite any general ceasefire and where international borders that might separate warring parties are absent. This criterion is applied by analyzing whether a mission succeeded in curbing large-scale violence, sustaining ceasefire agreements, and reducing the number of conflict-related casualties.

14 Diehl P., Druckman D. Evaluating peace operations. Colorado, 2010.

15 Martin-Brulé S. Evaluating Peacekeeping Missions: A Typology of Success and Failure in International Interventions. Routledge, 2017.

16 See also: Pushkina D. A Recipe for Success? Ingredients of a Successful Peacekeeping Mission. // International Peacekeeping. 2006. Vol. 13, iss. 2. P.133-149. 
- Criterion 2. Reduction of human suffering is another primary goal of peacekeeping missions. The UN is supposed to prevent atrocities against civilian populations, and peacekeeping missions are a major instrument towards achieving this goal. This criterion is operationalized by estimating the extent of any reduction in human rights abuses and the mission's success in resettling refugees.

- Criterion 3. Preventing the spread of conflict beyond the object state's borders is also important for ensuring regional security. An internal conflict can spread to other countries in the region, a process known as 'contagion'. To evaluate this criterion, the study assesses the extent to which the integrity of neighbouring countries has been kept intact as well as notes the overall regional (in) stability during UN mission's deployment.

- Criterion 4. Promoting conflict resolution is a final measure of the effectiveness of the UN mission. For peacekeeping, it requires the creation of a stable environment that is capable of preventing the recurrence of hostilities after the peacekeeping mission withdraws. This criterion will thus be assessed according to the extent to which the environment fostered by peacekeepers inhibits future violence. Progress towards positive peace (PPP) is evaluated based on whether there was progress made towards a settlement of the underlying conflict, such as onset/ progress/conclusion of negotiations and/or whether power-sharing arrangements have been put in place.

The definition of success offered in this article (limiting violence, reducing casualties, diminishing refugee flow, preventing conflict from spreading, and preventing war from recurring) does two important things: 1) it acknowledges the different nuances, voices, and forces - international and domestic, societal and institutional - affecting whether a mission may or may not be considered successful; 2) it insists that the human dimension remains the primary criterion for such considerations. A more nuanced consideration of "success" and a close look at so many cases is relevant not only to conceptual debates about these issues but also to "real" policy in the past, present, and future.

\section{Empirical Analysis}

Empirical analysis looks at 6 missions in Africa: these are all UN missions in Africa that originated after the Cold War and are over at present. Missions were coded as successful if they limited violent conflict; sustained cease-fires and/or oversaw a reduction in armed clashes; recorded no or few casualties within the mission, belligerent groups and civilian population; prevented occurrence of refugees/internally displaced people; stopped large-scale refugee crises from occurring and/or oversaw refugees/IDP's return; contained/prevented the spread of conflict beyond the borders of the conflict state; created a peaceful environment upon return (no recurrence of violence after the mission's departure or substantial contribution by the UN mission to (re)building state institutions and thus to PPP). Two missions fulfilled most or all of these requirements: UNTAG (Namibia) and ONUMOZ (Mozambique) are classified as successes. Alternatively, UNOSOM II (Somalia) and UNAMIR (Rwanda) were clear examples of failures. The other two cases: MINURCA (United Nations Mission in the Central African Republic) and ONUB (Burundi) fell into a gray area in which a mixture of success and failure were marked. 


\section{Successes}

UNTAG (United Nations Transition Assistance Group in Namibia). Over the course of the twentieth century, the demands for independence in Namibia continued to increase against the South African colonization. In spite of the fact that South Africa had had jurisdiction over Namibia since World War 1 in the form of a mandate, the Namibian people demanded independent governance ${ }^{17}$. These demands culminated in 1989 when the United Nations adopted Resolution 632 which promised aid in Namibia's pursuit of self-governance via the deployment of a peacekeeping mission. The mandate of the peacekeeping mission was to assist the Special Representative of the Secretary General in ascertaining Namibian independence. UNTAG was deployed to Namibia in April 1989 to ensure foreign troops' withdrawal and to ensure that this newfound independence was demonstrated through free and fair elections ${ }^{18}$. There were a number of other tasks included in the mission, amongst which were the formal emancipation of political prisoners, the assurance of the rule of law, and the removal of any and all discriminatory laws which were encoded within the former judicial system. Furthermore, it permitted the return of Namibian refugees, prevented intimidation within the period of political transition, and monitored the first elections within the country.

UNTAG fulfilled most of the aspects of its mandate. With regards to the first criterion of limiting violent conflict, the mission mostly sustained the cease-fire between the South African forces and the Namibian South West African People's Organization (SWAPO). The one exception to this came in April of 1989 on the day when the transition process was expected to begin, in which SWAPO launched a major offensive killing 30 personnel from the South African forces and about 300 of their own fighters. However, this early setback occurred before the peacekeeping forces were fully deployed and was followed by a relatively smooth peace process. The United Nations only lost 11 military personnel in all and only sustained $19 \operatorname{losses}^{19}$. As for the reduction of human suffering (criterion 2), there was a substantial return of refugees, bringing home more refugees from over 46 countries worldwide; this was done in accordance with a massive airlift in June of 1989 which was coupled with five reception centers to process and register returning refugees ${ }^{20}$. The Special Representative went further in attempting to ascertain a verifiable list of missing and unaccounted for Namibian citizens. Over the course of the peacekeeping operation, UNTAG successfully had reduced the list of unaccounted for civilians from 1,100 to $315^{21}$.

With regards to stymying the spread of conflict (criterion 3), UNTAG succeeded in preventing any destabilizing effect on the region. After UNTAG's departure, the warring parties of South Africa and Namibian guerrilla fighters ended, thus promoting the transition to positive peace. While the argument stands that there was never a significant potential for conflict following independence, one can also argue that SWAPO would not have been compelled to join the peace process were the UN to have been absent from the situation.

17 Dobbins J. et al. UN's Role in Nation-Building: From the Congo to Iraq // The RAND Corporation. 2001. P. 29.

18 UNTAG // United Nations. URL: peacekeeping.un.org/mission/past/untag.htm (accessed: 27.05.2019).

19 Ibid.

${ }^{20}$ Ibid.

${ }^{21}$ Ibid. 
In regard to the general body of literature, UNTAG is widely viewed as a success ${ }^{22}$. The relatively concise mission managed to achieve the objectives of the mandate, and since the initial intervention, the country has experienced overall peace. Thus, the fulfillment of the fourth criterion, the promotion of conflict resolution, and the creation of a stable environment have been demonstrated over time. In one analysis, the results of the mission were termed "near-ideal" 23 . President Hage Geingob himself was quoted in an interview stating that "UN diplomacy in Namibia played a major role in the independence process...It's because of the UN connection that we've been so successful" 24 . It was under the title of Prime Minister that Hage Geingob became the first leader of an independent, sovereign Namibia in 1990, which formal joined the United Nations. Despite Namibian history being largely dominated by foreign rule, and despite having had no previous history of democracy, the new nation overcame these odds. To further defend the success of the mission, scholars have pointed to the economic reconstruction efforts led by the peacekeepers to alleviate economic disparities through long term sustained growth ${ }^{25}$.

Currently, Namibia is facing some issues in terms of economic recession, however, the overall situation in the country is quite positive. Today, it is considered one of the more politically stable, democratic nations in Africa and boasts an upper-middle income population $^{26}$.

Although there has been some impact from neighboring wars, Namibia itself has proven resilient in maintaining a reconciliatory tone since granting amnesty to those who fought on both sides of the war of liberation. The nation functions under the rule of a multi-party parliamentary democracy which incorporates protection for human rights and establishes the independence of the judiciary, legislature, and executive presidency.

ONUMOZ (United Nations Operation in Mozambique). In 1975, Mozambique succeeded in gaining its independence from Portugal after nearly 500 years of colonization. In the years following, the impoverished nation suffered a volatile civil war between the new government and the Mozambican National Resistance (RENAMO) who were backed by South Africa's apartheid regime as well as Southern Rhodesia. It wasn't until 15 years later, in 1990, that the warring parties were put in contact through the Roman Catholic lay society of Sant'Egidio who began the orchestration of peace negotiations that lasted 2 years $^{27}$. The negotiations concluded in the form of a General Peace Agreement which was qualified by the inclusion of a United Nations Operation in Mozambique as established by the Secretary Council. The United Nations Operation in Mozambique (ONUMOZ) was mandated to monitor and support a ceasefire, demobilize forces and oversee the proceedings of national elections ${ }^{28}$. At the beginning of 1993, approximately

${ }^{22}$ Howard L. UN Peacekeeping in Civil Wars. P. 5; MacQueen N. United Nations Peacekeeping in Africa since 1960. Oxfordshire, 2014. P. 107.

${ }^{23}$ Dobbins J. et al. UN's Role in Nation-Building: From the Congo to Iraq. P. 42.

${ }^{24}$ Howard L. UN Peacekeeping in Civil Wars. P. 86.

25 Sparks D. et al. Namibia: The Nation after Independence. Boulder, 1992. P. 73.

26 Signé L. et al. Africa Is an Opportunity for the World: Overlooked Progress in Governance and Human Development. URL: https://brookings.edu/blog/africa-in-focus/2019/01/25/africa-is-an-opportunity-for-the-world-overlooked-progress-in-governance-and-human-development/ (accessed: 28.05.2019).

27 Dobbins J. et al. UN's Role in Nation-Building: From the Congo to Iraq. P. 93.

${ }^{28}$ ONUMOZ // United Nations. URL: https://peacekeeping.un.org/mission/past/onumozS.htm (accessed: 27.05.2019). 
6,500 troops were deployed under the leadership of the Secretary General's Special Representative, Aldo Ajello. A Supervisory and Monitoring Commission was established to ensure that the Agreement was implemented, while an additional humanitarian assistance program was simultaneously launched to help settle displaced persons.

The two-year mission was widely considered to be a success ${ }^{29}$. During the deployment of the ONOMOZ all major violence ceased (criterion 1). Demobilization was partially implemented: beginning in 1994, it eventually involved more than 76,000 soldiers from both sides, 10,000 of whom were integrated into the new national army with the help of ONUMOZ. Furthermore, the peacekeeping mission successfully collected around 155,000 weapons for confiscation, fulfilling another objective of the mandate ${ }^{30}$. While there were some cease-fire violations by RENAMO, overall violence was mitigated. Criterion 2 was implemented via a detailed investigation by UN peacekeepers on human rights abuses, thus further contributing to the stabilization of the situation. This in turn created a secure environment for the return and resettlement of refugees. By December of 1994, approximately 4.3 million people had returned to their original homes ${ }^{31}$. It is also important to note that during the mission's deployment, the conflict remained localized, thus the regional spread of violence was prevented (criterion 3). In October of 1994, the nation's first multiparty elections were held, carefully monitored by 2,300 civilian international observers ${ }^{32}$. The election was won by the Government's party, FRELIMO, winning both the parliamentary and presidential elections. Although RENAMO had threatened to boycott the elections, the party eventually participated under pressure from the United Nations ${ }^{33}$. The election was considered a success as approximately 5 million civilians registered to vote, and the outcome of the election was generally accepted.

Most importantly, the departure of the mission did not end international humanitarian aid, of which Mozambique has been an annual receiver. After the mission's withdrawal, large-scale violence did not recur (criterion 4), and Mozambique began the process of peace-building and reconstruction. Since the mission's departure, Mozambique has annually received over $\$ 1.7$ billion in development aid ${ }^{34}$. Given the country's numerous obstacles, the road to full-scale reconstruction has been challenging. Economic growth has averaged over seven percent during the last decade, and presidential elections are still held every five years since the original election in $1994^{35}$. The general consensus has been that ONOMOZ was largely successful, it fulfilled its mandate and paved the way for Mozambique to develop a sustainable political and economic system.

As of late, the situation in Mozambique has come under scrutiny. ICG reports note several crisis periods in the twenty-first century. Amongst these situations there have been included the tension in the run-up to the 2004 presidential election; violent clashes in

29 Dobbins J. et al. UN's Role in Nation-Building: From the Congo to Iraq. P. 103; Jett D. Preserving Peace in Mozambique // Foreign Affairs Magazine. 2016. URL: https://foreignaffairs.com/articles/ africa/2016-12-14/preserving-peace-mozambique (accessed: 26.05.2019).

${ }^{30}$ Jett $D$. Preserving Peace in Mozambique.

31 United Nations. The Blue Helmets: A Review of United Nations Peace-keeping. New York, 1990. P. 335.

32 ONUMOZ // United Nations.

33 Dobbins J. et al. UN's Role in Nation-Building: From the Congo to Iraq. P. 102.

34 Jett D. Preserving Peace in Mozambique // Foreign Affairs Magazine. 2016. URL: https:// foreignaffairs.com/articles/africa/2016-12-14/preserving-peace-mozambique (accessed: 26.05.2019).

35 Ibid. 
2005 between supporters of the ruling FRELIMO Party and the former rebel movement RENAMO over disputed municipal elections; riots against food and energy price increases (which were resolved by the government's agreement to lower prices and cut government spending) and the generalized fear of a return to civil strife and possible armed conflict. These fears have grown since 2013, as tensions between RENAMO and the FRELIMO-led government have continued to escalate. In 2016, a mass grave of 120 civilians was found in central Mozambique, believed by some scholars to have been the work of the government ${ }^{36}$. Approximately 12,000 Mozambicans have fled to neighboring countries since the middle of 2015, while survivors retell horrific stories of human rights violations ${ }^{37}$. Thus, while historically viewed as the epitome of a success story, the more recent events within the country have qualified such an evaluation. In light of the fact that almost 30 years have passed since the mission, it is difficult to ascertain the amount of responsibility that should be applied to the peacekeepers. For the time being, RENAMO retains its image of successfully fulfilling its mandate and aiding in the long-term development of the country.

\section{Failures}

UNAMIR (United Nations Mission in Rwanda). Deployed originally to monitor the Arusha accords, UNAMIR is generally accepted to be a failed mission in terms of implementation of its mandate (though the mandate had various incarnations, the mission hardly accomplished any of them) and prevention of genocide. It has been argued many times that this was less the fault on the part of peacekeepers who failed to serve the goals of international peace and security and more on the part of the United Nations Security Council and the United Nations failing to act in a timely manner and to handle the crisis accordingly. The mission lasted from October 1993 until March of 1996. The mission was orchestrated after the end of the Rwandan civil war which had begun in 1990. The signing of the Arusha accords was the ceasefire compromise created between the warring parties of the Rwandan government, which primarily consisted of Hutus, and the Tutsi dominated rebel forces formally known as the Rwandan Patriotic Front (RPF). Additional tasks of the UNAMIR mandate included the peaceful oversight of new elections, monitoring repatriation of Rwandan refugees who had fled the country, assistance in the coordination of humanitarian relief, and the investigation of some police and gendarmerie activities ${ }^{38}$. Its authorized strength was 2,500 personnel, however, that number was not achieved for some months.

The criteria below should help to clarify how UNAMIR implemented various peace and humanitarian measures. As regards the first criterion of limiting violent conflict, major ceasefire violations occurred. In the end, the cease-fire was broken irrevocably due to the military victory of the RPF, with large-scale war reoccurring. The violence was only put to an end with the intervention of the RPF and French forces. In terms of human suf-

36 Bowker T. et al. Mozambique's Invisible Civil War // Foreign Policy. 2016. URL: https://foreignpolicy.com/2016/05/06/mozambiques-invisible-civil-war-renamo-frelimo-dhlakama-nyusi/ (accessed: 01.06.2019).

37 Ibid; Mozambique: Mass Flight Over Reported Army Abuses // Human Rights Watch. 2016. URL: https://hrw.org/news/2016/02/22/mozambique-mass-flight-over-reported-army-abuses (accessed: 04.06.2019).

38 UN Security Council. Resolution 872 (1993) Adopted by the Security Council at its $3288^{\text {th }}$ meeting. 1993. URL: https://undocs.org/S/RES/872(1993) (accessed: 01.06.2019). 
fering (criterion 2), the UN peacekeepers did little to stand in the way of one of the most infamous tragedies. On 6 April 1994, a plane carrying Rwandan president Habyarimana was shot down, killing him and the president of Burundi who was also on board. This signalled the beginning of the Rwandan genocide, in which over a period of 100 days, approximately 800,000 Rwandan Tutsis and Hutu moderates were murdered. UNAMIR's commander, Romeo Dallaire, had heard that the government may have been planning mass extermination of the minority group as early as January of $1994^{39}$. The Hutu dominated government was rapidly arming militias in secret arms caches. Reportedly, Dallaire had requested permission to said weapons caches, a request which was refused on the grounds of exceeding the mandate ${ }^{40}$.

Large-scale refugee and IDP outflows occurred - about 2 million fled to other countries, and as many as 2 million people were internally displaced ${ }^{41}$. It should be said, however, that due to force reductions by the U.N. Security Council and in the absence of an enforcement mandate, it is notable that the 2000 peacekeepers remaining in the country managed to protect about 15,000 civilians from the massacres. In general, however, the conflict significantly destabilized the regional situation (criterion 3), affecting Burundi, Zaire (now the Democratic Republic of the Congo) and Tanzania. As the conflict ended in the clear military victory of the RPF, it arguably gave President Kagame a free hand to intervene later in the conflict in the DRC, which evolved to become "the Great War of Africa." Overall, UNAMIR had no major impact on conflict abatement or stabilization and did not appear to contribute to conflict resolution in the country (criterion 4). Since the end of the genocide, RPF has been in power in Rwanda and in 2003 and 2010, Paul Kagame was elected as the President. The International Criminal Tribunal for Rwanda was set up to examine the crimes committed in 1994. In June 2013, the ICTR Prosecutor handed in the last case connected to genocide.

The case of Rwanda is one of the most evident failures of the U.N. Peacekeeping operations. That being said, the experience demonstrated the changes that were necessary within the concept of peacekeeping to better work for future operations. For example, the notion of "Responsibility to Protect" (R2P) sprung from the tragedies of the 1990s, Rwanda included. As the aforementioned example of Dallaire's rejected proposal to search the weapons cache showed, mandates need to be written in a manner that allows peacekeepers to achieve the objective of ensuring peace. This also meant the allotment of troops. The original design which ascertained approximately 2,500 troops could never have prevented a massacre on the scale that it occurred in Rwanda. The United Nations realized late that in order to achieve such a demanding mandate, there would need to be reinforcements. This occurred in the successor mission, UNAMIR II, which delivered 5,500 troops, personnel carriers, and other needed equipment ${ }^{42}$. Naturally, this realization was too little, too late, however it did lay the groundwork for future missions.

Only this year did Rwanda mark the $25^{\text {th }}$ anniversary since the genocide occurred. Today, Rwanda remains under the leadership of Paul Kagame after an alteration of the

${ }^{39}$ Dallaire R. et al. Shake Hands with the Devil: The Failure of Humanity in Rwanda. Toronto, 2003. P. 150 .

40 Ibid. P. 146.

${ }^{41}$ UNAMIR // United Nations. URL: https://peacekeeping.un.org/en/mission/past/unamirS.htm (accessed: 03.06.2019); United Nations. The Blue Helmets: A Review of United Nations Peace-keeping. New York, 1990. P. 542.

${ }^{42}$ Melvern L. Conspiracy to Murder: The Rwanda Genocide. London, 2004. P. 299. 
Rwandan Constitution in 2015 to allow for a longer time in office ${ }^{43}$. Under his rule, there have been many accusations of human rights abuses, political restrictions including detentions and torture, and misconduct by authorities ${ }^{44}$. Economically, Rwanda is doing quite well with a fast growing economy and a decline in poverty rates ${ }^{45}$. Therefore there has been a fair amount of development in the nation, in spite of the still contentious debates surrounding the legacy of the genocide.

UNOSOM II (United Nations Operation in Somalia). In 1991, Somalia's long-time leader, Mohamed Siad Barre, was ousted, and the former British protectorate of Somaliland declared unilateral independence. Militiamen from the United Somali Congress occupied the presidential palace but coup leaders were unable to build a unified government, thus causing a civil war that led to the deaths of thousands of civilians.

UNOSOM II was preceded by UNOSOM I, a smaller observation mission, as well as UNITAF, an UN-authorized enforcement mission led by the United States. UNITAF's goal was the restoration of security and UNOSOM II was expected to take over for UNITAF. Deployed in March of 1993, the force had a strength of 28,000 personnel, including 22,000 troops, civilian staff, and logistics officers numbering $8,000^{46}$. This mission in particular was backed by strong popular support from the United States, as a continuation of its initial UNITAF. The duration of the short mission was dominated by an intense pursuit of Mohammad Farah Aidid, a Somali warlord who had expressed an interest in pursuing presidency. However, this focus distracted from the primary objective of the mission, and eventually it resulted in severe civilian casualties. This in turn led to anti-U.N. sentiment culminating in a protest by Somali citizens, which further exacerbated tensions when Pakistani peacekeeping troops reacted by firing into the crowd, killing 20 citizens ${ }^{47}$. This consequentially antagonized Somali citizens who began favoring the warlords over the peacekeepers. The infamous "Battle of Mogadishu" in 1993, popularized by the film "Black Hawk Down", led to the death of 18 American soldiers and effectively ended the U.S.'s support for peacekeeping in the country.

In March 1995, UNOSOM II completely withdrew from Somalia after suffering heavy casualties. The majority of UNOSOM's mandate was left unaccomplished. The mission failed to limit violence (criterion 1) as there was a renewal of civil war during its presence, with heavy casualties in which several civilian massacres occurred. Moreover, U.N. clashes with Aideed led to the death of 6,000 Somalis in Mogadishu ${ }^{48}$. The mission

43 Cowell A. Rwanda Marks 25 Years Since the Genocide. The Country Is Still Grappling With Its Legacy // The New York Times. 06.04.2019. URL: https://nytimes.com/2019/04/06/world/africa/rwandagenocide-25-years.html (accessed: 06.06.2019).

44 Ibid.

45 Rwanda Economy: Population, GDP, Inflation, Business, Trade, FDI, Corruption. URL: https:// heritage.org/index/country/rwanda (accessed: 06.06.2019).

${ }^{46}$ DiPrizio R. Armed Humanitarians: U.S. Interventions from Northern Iraq to Kosovo. Baltimore, 2002. P. 48 .

47 Lorch D. 20 Somalis Die When Peacekeepers Fire at Crowd // The New York Times, 14.06.1993. URL: https://nytimes.com/1993/06/14/world/20-somalis-die-when-peacekeepers-fire-at-crowd.html (accessed: 30.05.2019).

48 Thakur $R$. The United Nations, Peace and Security from Collective Security to the Responsibility to Protect. Cambridge, 2006. P. 102; Patman R. Disarming Somalia: The Contrasting Fortunes of United States and Australian Peacekeepers during United Nations Intervention, 1992-1993 // African Affairs. 1997. Vol. 96, iss. 385. P. 509. 
also failed to reduce human suffering (criterion 2) - flagrant human rights violations were widespread, and although there were marginal refugee returns (about 3,000 people had returned from Kenya) $)^{49}$, there were also refugees outflows. Overall, the mission might have even contributed to escalating conflict. The presence of UN peacekeeping forces appeared to generate considerable tensions between the parties to the conflict, particularly after heavy-handed peacekeeper attempts to track down and eliminate warlords, leading to a considerable number of civilian casualties. This allowed militants to exploit public sentiment against UN forces and led to a serious decline in trust and confidence in UNOSOM. Eventually, a string of attacks on peacekeepers highlighted that their position in Somalia had become untenable.

In the immediate aftermath of UNOSOM's departure, there was no regional spread of the conflict, so the mission may be partially granted credit for this (criterion 3 ). However, by 2006, the rise of the Islamic Courts Union (ICU) spurred increased conflict in Mogadishu after secular warlords, funded partly by the United States Central Intelligence Agency, grouped together to form the Alliance for the Restoration of Peace and CounterTerrorism (ARPCT). Ethiopia intervened in the conflict in support of the secular warlords and factions, and ICU was eventually defeated by a timely offensive. U.S. Special Forces and an African Union Peacekeeping operation (AMISOM) were both deployed in an attempt to control Islamist and Al-Qaeda factions as well as the resurgence in inter-tribal fighting. Unfortunately, the withdrawal of Ethiopian troops in 2008 critically undermined these efforts. In 2011, a severe drought and famine hit Somalia, exacerbated by the obstruction of aid by militants. The combined effects of famine, war and social collapse have deeply scarred Somalia, and are proving to be serious impediments to stabilization (criterion 4). 2012 witnessed a renewed interest in Somalia by the international community the UNSC approved the UN Political Mission to Somalia (UNSOM) to support "peace and reconciliation", assist the government and AMISOM in peace and state building, and monitor rights violations. But in July 2013, ICG put Somalia on high alert for the risk of conflict once again, thus leaving Somalia still one of the darkest failures of UN peace efforts to date.

As of 2019, Somalia remains one of the most fragile states worldwide, showing little sign of future improvement. The number of internally displaced people has reached an estimated 2.7 million, with civilians living under the harsh control of Islamist armed group Al-Shabab who often carry out deadly attacks against the civilian population ${ }^{50}$. In the first eight months of 2018, over 204,000 people have been forcibly evicted, while another 30,000 have been left homeless after the demolition of dozens of informal settlements by security forces ${ }^{51}$.

\section{Partial Success/Failure}

MINURCA (United Nations Mission in the Central African Republic). After the fall of the Soviet Union in 1991, calls for democracy in the Central African Republic grew. Due to the growing amount of unrest and international pressure, the military leader An-

49 United Nations. The Blue Helmets: A Review of United Nations Peace-keeping. P. 306.

50 World Report 2019: Rights Trends in Somalia. Human Rights Watch. 17 Jan. 2019. URL: https:// hrw.org/world-report/2019/country-chapters/somalia (accessed: 05.06.2019).

51 Ibid. 
dre Kolingba agreed to the creation of national elections beginning in 1993. A new constitution was written the following year, however, it did little to stabilize the shifting powers in government. By 1996, the Central African Republic had suffered three successive mutinies by elements of the armed forces leading to instability, widespread destruction of property and infrastructure, and heightened tension within the country.

In 1997, the conflicting parties came together to sign the Bangui Agreements. The Inter-African force in the Central African Republic (MISAB) was authorized by the U.N. Security Council to monitor the agreements. As France was preparing to withdraw its troops, and consequently its logistical support for MISAB, the UNSC authorized the deployment of peacekeeping mission MINURCA. According to the UN's own evaluation, MINURCA was successful in its implementation as it did improve the security situation in the country during its deployment, especially in the capital (criterion 1). In his last report on MINURCA, the Secretary-General stated that through their presence and active role in the Central African Republic, MINURCA, its predecessors and MISAB together had provided the people and government of the Central African Republic with "much needed stability and breathing space after a period of serious upheaval"52. The Security General further claims that MINURCA's presence was essential to the peaceful implementation of legislative and presidential elections and the creation of major political, social and economic reforms. At the same time, the Secretary-General noted that important challenges that still lay ahead for the nation - the government would need to do its utmost to build on the gains made during MINURCA's presence and continue to work resolutely towards genuine democracy and economic recovery.

The UN's evaluation of its work is accurate in the sense that the MINURCA mission did significantly improve the situation in the country. However, it is important to recognize that many worried about what might happen after the mission ended. In fact, the situation in the Central African Republic has indeed deteriorated significantly since then, thus calling into question the mission's effectivenessas far as the success of conflict resolution is concerned). In this case it seems that this turn of events is most appropriately considered a criticism of the UN SC for not extending the mission rather than of peacekeepers' performance. Thus, the mission fared reasonably well in all except in one of the measures of success given in this project: contribution to conflict resolution (criterion 4). The mission ended the violence that had broken out in 1996-1997 and kept a watchful eye on the 1999 elections in which incumbent President Patassé maintained political control. The mission formally ended in January 2000, as a rebuilding mission (BONUCA) took over. The United Nations deemed the mission a success and encouraged the government to continue on the path of national reconciliation and growth.

MINURCA's overall and long-term impact is somewhat difficult to judge. Whilst the mission itself made a significant contribution to bolstering and consolidating stability in the country, the overall impression is that the U.N. and the international community seem to have taken only a half-hearted approach in assisting the country with it considerable security problems and governance failures - including the deplorable human rights situation (criterion 2). Although at the time of deployment, MINURCA provided much-needed security and political measures for the country, the mission's discontinuation (although it was later followed by MINURCAT) is likely to have contributed to the current situation.

${ }^{52}$ MINURCA // United Nations. URL: https://peacekeeping.un.org/mission/past/minurcaB.htm (accessed: 30.05.2019). 
An ICG report published in 2013, stated that 'the coup by the Seleka rebel coalition in March 2013 that ended François Bozizés decade-old rule plunged the Central African Republic into a new and dangerous crisis... the collapse of the state and the disappearance of security forces from a large part of the territory may turn the Central African Republic (CAR) into a source of instability in the heart of Africa [criterion 3]... The humanitarian situation is deteriorating: the population is suffering from deprivation, which will be compounded by the rainy season, and there are some 150,000-180,000 internally displaced people"53. In the Fragile States Index of 2019, CAR was placed in the "High Alert" category for fragile states deserving of international attention.

ONUB (United Nations Operation in Burundi). Beginning with Burundi's independence in 1962, the country would go on to experience years of civil war, genocide, and ethnic cleansing. A decade-long civil war, in which an estimated 300,000 civilians were killed ${ }^{54}$, ended formally with the signing of the Arusha Peace and Reconciliation Agreement on 28 August 2000. The Agreement was signed between the Tutsi President Pierre Buyoya and the Hutu rebel forces, with a plan to implement a new transitional government as part of the pact. The new government was within its 5-year trial period during which ONUB was formed and deployed in 2004. The mandate of the mission was to oversee the proper implementation of the Arusha Agreement, including mutually followed ceasefires, disarmament and demobilization of militias, and the contribution to the creation of security conditions for humanitarian assistance amongst other objectives ${ }^{55}$. The mission deployed approximately 5,600 military personnel at its peak ${ }^{56}$.

ONUB has been noted by the UN as one of the most successful $21^{\text {st }}$ century missions. Using a wide range of criteria, there is no doubt that ONUB performed well in Burundi, fulfilling most aspects of its mandate by high standards. In particular, it showed excellent levels of resolve and capacity for helping mediate agreements between often cynical, distrustful and fractious political units and parties. Furthermore, as noted in an independent review by Stephen Jackson of the Conflict Prevention and Peace Forum, the mission managed to mediate between these groups with consideration for an "understandably weary population" 57 . In addition to successfully assisting political transition and a series of elections (criterion 4), the mission also relieved some of the worst threats to security in the country, even if it was unable to entirely prevent sporadic outbreaks of violence in certain regions (criterion 1). Some more recent issues in the country have qualified such positive feedback, however for the time being, the mission is still considered largely successful. Some serious criticisms can still be made, particularly with regards to reduction in human suffering.

Firstly, whilst security was generally improved across Burundi, as noted above, the incidence of violence towards various groups such as women, children and various mi-

53 Central African Republic: Priorities of the Transition // Crisis Group. 18.08.2016. URL: https:// crisisgroup.org/africa/central-africa/central-african-republic/central-african-republic-priorities-transition (accessed: 30.05.2019).

${ }^{54}$ BurundiCountry Profile. BBCNews.3.12.2018.URL:https://web.archive.org/web/20111007175839/ http://news.bbc.co.uk/2/hi/africa/country_profiles/1068873.stm (accessed: 05.06.2019).

55 United Nations. ONUB: United Nations Operation in Burundi - Mandate // United Nations. URL: https://peacekeeping.un.org/en/mission/past/onub/mandate.html (accessed: 05.06.2019).

56 Ibid.

57 Jackson S. The United Nations Operation in Burundi (ONUB) - Political and Strategic Lessons Learned. Conflict Prevention and Peace Forum. New York, 2006. 
norities remained high, perhaps even increasing if taking into account the transformation of such abuses from politically based perpetration to quasi-political criminal activity. Human rights in general could have been - and could still be - much better and stand out as a significant shortcoming in ONUB's mandate (criterion 2). Although perhaps difficult for ONUB to have prevented, particularly in the early stages of the mission, the Gatumba massacre serves to tarnish an otherwise respectable peacekeeping record. Secondly, while ONUC contributed significantly to refugee return, the precarious situation in the country prevented a high rate of IDP return, with approximately 100,000 civilians still displaced in $2009^{58}$. Moreover, the rate of returning refugees significantly slowed at the beginning of 2006, due to instability with regard to security and food. Furthermore, the issues over land ownership also contributed to the problem. These numbers improved in 2009, with the UNHCR aiding more than 32,000 Burundian refugees with reintegration into society through the creation of national identity cards, cash grants, and food rations ${ }^{59}$.

Overall, ONUC can be called one of the more successful of the partially successful missions, and it can be established that it has made an important contribution to conflict abatement. The spread of regional conflict remained low over the course of the mission (criterion 3), and peacekeepers worked diligently with local government officials. At the same time, even in the final year of activity, the security situation in Burundi remained tense, as reported by the final progress report in which "The incidence of crime, including murder, theft and rape, remained high" ${ }^{60}$. The situation further deteriorated, with a 2012 ICG report stating that "since the 2010 boycotted elections, Burundi is steadily drifting away from what was initially regarded as a peacemaking model, and violence from both the ruling party and the opposition is threatening stability" 61 . This evidence demonstrates that despite some mild successes by ONUB, the mission fails to score high on conflict resolution measures, despite it being one of the mission's main objectives. Burundi has only further deteriorated since, with another crisis decimating the country in April of 2015 after President Nkurunziza announced that he was running for office for a third term in spite of dispute: because of this, the country has been plagued by widespread human rights abuses including executions, rapes, abductions, and intimidation against other political leaders ${ }^{62}$. Thus, although the mission of ONUB was and is still considered a success, its fulfilment of the fourth criterion has been put into question by these recent events.

\section{Conclusion}

This paper has examined $6 \mathrm{UN}$ peacekeeping missions in Africa - these are all PKOs that originated after the end of the Cold war and have been completed at the time of paper writing. The paper offers new criteria for evaluating peacekeeping missions and finds that 2 out of the examined missions succeeded across most of the criteria, 2 failed and 2 fell

${ }^{58}$ United Nations. UNHCR Global Report 2009 - Burundi. URL: https://unhcr.org/publications/ fundraising/4c08f1a89/unhcr-global-report-2009-burundi.html?query=burundi (accessed: 07.06.2019).

59 Ibid.

${ }^{60}$ United Nations Security Council. Ninth report of the Secretary-General on the United Nations Operation in Burundi. 18.12 2006. URL: https://undocs.org/S/2006/994 (accessed: 07.06.2019).

${ }^{61}$ Burundi: Bye-Bye Arusha? // Crisis Group. 25.10.2012. URL: https://crisisgroup.org/africa/centralafrica/burundi/burundi-bye-bye-arusha (accessed: 07.06.2019).

62 World Report 2019: Rights Trends in Burundi // Human Rights Watch. 17.01.2019. URL: https:// hrw.org/world-report/2019/country-chapters/burundi/ (accessed: 07.06.2019). 
into the gray area of partial success-partial failure. The most important observation that can be made from this classification is that in several cases the overall assessment does not overlap with mandate implementation. For example, ONUB in Burundi, despite fulfilling most of the mandate's objectives and classified by the UN as one of its most successful missions is placed in the partial success/failure group, mostly due to the current instability in Burundi, hence, UN's weaker contribution in progress towards positive peace.

With regards to various criteria of success, UN peacekeeping has been particularly unsuccessful in preventing genocide and/or civilian massacres. Varying success was demonstrated in limiting violence, preventing violent deaths and refugee and IDP resettlement/preventing outflows. UN missions have been fairly successful in preventing conflicts from spreading and creating regional instability. With regards to conflict resolution measures, UN missions performed better in preventing reoccurrence of war within two years after departure, but UN peacekeeping has been less successful at contributing to progress towards positive peace (PPP measure).

The difference between evaluation of the missions based solely on mandate implementation versus on their contribution to limiting violence, reducing human suffering, preventing conflict spread, preventing the recurrence of war and contributing to PPP leads to a deeper understanding of whether UN SC is making the right decisions for particular situations and whether UN peace operations are indeed utilizing all of their potential for bringing stability to the world. Successful missions offer support for an optimistic outlook. Partial successes, especially those of missions deployed in the midst of on-going wars, reinforce this optimism but offer a word of caution to avoid too demanding expectations of UN troops. Finally, failed missions should never be forgotten or under-analyzed in order not only to avoid mistakes in the future but also not to place all blame on peacekeepers as opposed to the decision-making bodies.

\section{References}

Brown M. (ed.) International Dimensions of Internal Conflict. Cambridge, MIT Press, 1996, 653 p.

Cousens E. et al. Peacebuilding as Politics: Cultivating Peace in Fragile Societies. Boulder, Lynne Rienner Publishers, 2000, 248 p.

Dallaire R., Beardsley B. Shake Hands with the Devil: The Failure of Humanity in Rwanda. Toronto, Random House Canada Publ., 2003, 562 p.

Diehl P. F. International Peacekeeping. Baltimore, John Hopkins University Press, 1993, 211 p.

DiPrizio R. C. Armed Humanitarians: U.S. Interventions from Northern Iraq to Kosovo. Baltimore, Johns Hopkins University Press, 2002, 234 p.

Doyle M.W., Sambanis N. Making War and Building Peace: United Nations Peace Operations. Princeton, Princeton University Press, 2006, 424 p.

Fortna V.P. Does Peacekeeping Work? Shaping Belligerents' Choice After Civil War. Princeton, Princeton University Press, 2008, 232 p.

Galtung J. Violence, Peace, and Peace Research. Journal of Peace Research, 1969, vol. 6, iss. 3, pp. 167-191.

Heldt B., Wallensteen P. Peacekeeping Operations: Global Patterns of Intervention and Success, 1948-2004. Stockholm, Folke Bernadotte Academy Publications, 2007.

Howard L. M. UN Peacekeeping in Civil Wars. Cambridge, Cambridge University Press, 2008. 418 p.

Jo J. I. The UN's Effectiveness in Post Civil War Peace Durability. Journal of International and Area Studies, 2006, vol. 13, iss. 1, pp. 23-35.

MacQueen N. United Nations Peacekeeping in Africa since 1960. New York, Routledge Publ., 2014, 328 p.

Martin-Brulé S. M. Evaluating Peacekeeping Missions: A Typology of Success and Failure in International Interventions. New York, Routledge Publ., 2017, $154 \mathrm{p}$.

Melvern L. Conspiracy to Murder: The Rwanda Genocide. New York, Verso Publ., 2004, 358 p. 
Paris R. At War's End Building Peace after Civil Conflict. Cambridge, Cambridge University Press, 2004, $289 \mathrm{p}$.

Patman R. G. Disarming Somalia: The Contrasting Fortunes of United States and Australian Peacekeepers during United Nations Intervention, 1992-1993. African Affairs, 1997, vol.96, iss. 385, pp. 509-533.

Pugh M. Peacekeeping and Critical Theory. International Peacekeeping, 2007, vol. 11, iss. 1, pp. 39-58.

Pushkina D. A Recipe for Success? Ingredients of a Successful Peacekeeping Mission. International Peacekeeping, 2006, vol. 13, iss. 2, pp. 133-149.

Sparks D. L., December G. Namibia: The Nation after Independence. Boulder, Westview Press, 1992, 204 p.

Stedman J.R. et al. Ending Civil Wars: The Implementation of Peace Agreements. Boulder, Lynne Rienner Publishers, 2002, $775 \mathrm{p}$.

Thakur R. C. The United Nations, Peace and Security from Collective Security to the Responsibility to Protect. Cambridge, Cambridge University Press, 2006, 406 p.

Wood R. M., Kathman J. D., Gent S. E. Armed Intervention and Civilian Victimization in Intrastate Conflicts. Journal of Peace Research, 2012, vol. 49, iss. 5, pp.647-660.

Статья поступила в редакцию 5 июля 2019 г.

Рекомендована в печать 2 декабря 2019 г.

Received: July 5, 2019

Accepted: December 2, 2019 